\title{
RÜSz-Fogarasi ENIKŐ*
}

\section{A KORA ÚJKORI KOLOZSVÁRI ISPOTÁLYMESTEREK}

\author{
Kulcsszavak: kora újkori Kolozsvár, városi kormányzat, ispotály, ispotálymester, szegények
}

Az erdélyi kora újkori ispotályok története a szekularizált szegénygondozás korszakát jelenti. Az egyházi vagyonok szekularizációja a katolikus egyházat megfosztotta anyagi bázisától, az újonnan létrejött egyházak még túl erőtlenek voltak ahhoz, hogy meghatározó szerepet játszszanak ebben a kérdésben. Ezentúl, a városi közösségek felelősnek érezték magukat a szociális kérdések megoldásában. Az új állam keretei között zajló szociális és beteggondozás sajátosságai nem az új viszonyoknak köszönhetőek, hanem a kora újkori társadalmi, egyházi és gazdasági átalakulások nyomják rá bélyegüket. Ezeknek a feladatoknak a fejedelemség kori Erdélyben a helyszínei, központjai az ispotályok. Ezek az intézmények a középkorban elképzelhetetlenek az egyháztól függetlenül, a kora újkorban viszont az egyházzal való kapcsolatuk a legnehezebben érzékelhető.

A magyar nyelvű kora újkori forrásokban azokat az intézményeket, ahol a szegény rászorulók gondját viselték ispotály megnevezéssel illették. Erdélyben a kora újkori Nagyszebenben, Besztercén, Brassóban a latin és német forrásokban a spital, hospital kifejezés volt a leggyakoribb, emellett a xenodochium megnevezés is használatos volt. ${ }^{1}$

A kora újkori forrásokban az ispotály vezetőjét más és más kifejezéssel illették, így Marosvásárhelyen ispotálybírónak és ispotálymesternek, ${ }^{2}$ Nagyszebenben ispotályatyának, ${ }^{3}$ Kolozsváron ispotálymesternek. ${ }^{4}$ Ezek a megnevezések magukban hordozták az ispotály vezetojjének státusát, de a városi adminisztrációban elfoglalt helyét is. Marosvásárhelyen az ispo-

* Rüsz-Fogarasi Enikő, dr. (1966), várostörténész. 1991-1994 között a Babeş-Bolyai Tudományegyetem Középkor-történeti és Történetírás Tanszékén gyakornok, 1994-től tanársegéd, 1998-tól adjunktus, 2004-től egyetemi docens. A történettudományok doktora (1999), disszertációját az erdélyi középkori városok kiváltságairól és kötelességeiről írta. Három önálló kötet, egyetemi jegyzetek és forráskiadások szerzője, a késő középkori és kora újkori várostörténet területén több mint ötven tanulmánya jelent meg. 2011-ben habilitált az ELTE Bölcsésztudományi Karán, 2008-tól a BBTE Történelem és Filozófia Kar magyar oktatásért felelős dékánhelyettese.

1 Petre Beşliu Munteanu: Spitalul medieval din Sibiu. Honterus, Sibiu, 2008; Derzsi Júlia: Organizarea acțiunilor caritabile din Sibiu în deceniile de după Reformă. Historia Urbana XVIII(2010). 63-76.

2 Berekméri Róbert: A marosvásárhelyi ispotály az Erdélyi Fejedelemség korában (1629-1702) = Marosvásárhely történetéből. 3. Szerk. PÁL-AnTAL Sándor-Simon Zsolt. Mentor, Marosvásárhely, 2013. 9-40.

3 Beşliu Munteanu: i. m. 11-12.

4 Rüsz-Fogarasi Enikő: Egy elfeledett intézmény. A kolozsvári Szentlélek ispotály története. L'Harmattan, Bp., 2012. (a továbbiakban Rüsz-Fogarası 2012) 
tály élén két személy is állt, az ispotálybíró, aki az ispotálymester munkáját ellenőrizte, és maga az ispotálymester, aki gazdálkodott az ispotály vagyonával. ${ }^{5}$

A fejedelemség kori Kolozsváron rövid ideig három, huzamosabb ideig pedig két ispotály működött párhuzamosan. ${ }^{6}$ A Szent Erzsébet-ispotály a 14. századtól kezdődően napjainkig folyamatosan müködő kolozsvári szociális intézmény. A 15. század végén egy másik ispotály is megjelent a forrásokban, ez a Szentléleknek szentelt intézmény, amely megszakítás nélkül múködött a 16. és a 17. században, addig, ameddig a hetedik évtizedében beolvadt a Szent Erzsébet-ispotályba. Ezzel is magyarázható, hogy a Szentlélek-ispotályt a fejedelemség kori Kolozsvárra vonatkozó feldolgozások többnyire nem ismerték. A 16. század néhány évtizedén keresztül a járványos betegek számára egy harmadik intézmény, a Szent Jóbról elnevezett ispotály is múködött. Erről az utóbbiról csupán néhány szórványos adattal rendelkezünk, de a két másik létesítménnyel kapcsolatban gazdag forrásanyag maradt ránk. A két ispotály tevékenysége nyomán keletkezett források és ezek feldolgozása nagyon szépen megvilágítja a kora újkori szociális intézmények gazdálkodását és mindennapjait. Ebben a tevékenységben a kulcsfigura az ispotálymester volt.

De hadd lássuk a fejedelemség korában ki az, aki kinevezi ezeket a személyeket, kik közül, kik azok, akik meghatározták feladatköreiket, kinek kell számot adniuk, milyen gyakran cserélnek gazdát ezek az intézmények, lehet-e tudni milyen helyet foglaltak el az ispotálymesterek a város polgárai között?

Minden szabad királyi városban a város statútumainak, szabályainak megfelelően nevezték ki az ispotály vezetőit, feladataikat - akárcsak a többi városvezető tisztségviselő esetében - a város hatósága szabta meg. A kolozsvári ispotályokat a kora újkorban az ispotálymesterek vezették. Őket a százférfiak tanácsából, az úgynevezett centumvirek közül választották, akárcsak a város többi tisztségviselőit. Az ispotálymesteri tisztség a fejedelemség korában az egyik fontos, választás alapján betölthető tisztségnek számított Kolozsváron. A városigazgatásban szerepet játszó személyek közül - főbíró, királybíró, két sáfárpolgár, két direktor, ${ }^{7}$ számvevők, két ispotálymester, postamester, divizorok, ${ }^{8}$ ispánok, vásárbírók, adószedők, ${ }^{9}$ tóbírák, erdőbírák, borbírák, serlátók, építőmesterek, cipósüttető urak - az ispotálymesterség az egyik jelentős hivatal volt. Minden tisztségre való választás a százférfiak tanácsában történt, akik a saját soraikból a megfelelő emberekre bízták a különböző feladatokat. A megbízott, megválasztott személyek mindannyian a nagy tanács tagjai és egyben a város vagyonos, közmegbecsülésnek örvendő polgárai voltak.

A korábbi irodalom úgy gondolta, hogy az ispotálymesteri tisztséget is mindig a városi két náció felváltva viselte. Ez a meggyőződés az 1568-as, a szászok és magyarok által is elfogadott, unió értelmezéséből fakad, amely többek között előírja, hogy az egyházi vagyonok és kórhá-

5 BEREKMÉRI: $i$. $m$.

6 BENKő Elek: Kolozsvár magyar külvárosa a középkorban. A Kolozsvárba olvadt Szentpéter falu emlékei. EME, Kvár, 2004 (Erdélyi Tudományos Füzetek 248). 49-51; Rüsz-Fogarasi 20 I 2. 8-9.

7 PAкó László: A városi közügyigazgatók (direktorok) Kolozsvár 16. század végi birósági gyakorlatában. Erdélyi Múzeum LXXIV(2013). 3. sz. 88-102.

8 Kovács Kiss Gyöngy: A kolozsvári osztóbirák intézménye = Uó: Rendtartás és kultúra. Századok, mindennapok, változások Erdélyben. Mentor, Marosvásárhely, 2001.25-39.

9 Kiss András: Más források - más értelmezések. Mentor, Marosvásárhely, 2003. 177. (a továbbiakban Kiss 2003) 
zak ügyeit is a két náció polgárai felváltva viseljék. ${ }^{10}$ Azonban, ha figyelemmel kísérünk egy adott intézményt, esetünkben a Szentlélek, de akár a Szent Erzsébet-ispotályt is, már teljesen elbizonytalanodunk; gyakran előfordul, hogy az utód ugyanabból a nemzetből való volt. Meglátásunk szerint, ezt a szabályt sokkal rugalmasabban kezelték, mint gondolnánk. Betartották ugyan, de a nációk szerinti elosztás az összes hivatalra vonatkozott, és bizonyára a paritás elvét ilyen szinten tartották számon. Még ha a két hosszabb időszakon keresztül múködő ispotályt is vizsgáljuk, akkor sem lehet minden esetben a paritás elvének a követését egyöntetüen kimutatni, sőt az sem bizonyítható, hogy ha az egyik intézmény élén szász állt, a másik ispotályt magyar vezette.

Egyébként, Kolozsvár vallási összetételének tekintetében a 17. század elején jelentős változásoknak lehetünk tanúi, ugyanis az unitárius többség mellett egyre jobban előretört a református közösség. Ezt a tendenciát segítette az unitárius egyház megtörésére irányuló dési komplanáció kikényszerítése. ${ }^{11}$ A fejedelem és az unitárius egyház által 1638-ban aláírt egyezmény olyan dogmatikai tételeket fogadtatott el az unitárius egyházzal, amelynek természetes következménye az unitárius vallás és egyház hanyatlása, háttérbe szorulása volt. Ezzel párhuzamosan, a református fejedelmek uralkodásától kezdődően a református egyház pozíciói egyre hangsúlyosabbá váltak. Kolozsváron is érezhetővé váltak ezek a változások, a református egyháznak egyre több híve lett a városban, mintegy ellensúlyozva az unitáriusok egykori többségét. A város vezetésében azonban ez nem tükröződött, hiszen a város hivatalainak elosztásában a nációnkénti elosztást alkalmazták 1655-ig. ${ }^{12}$ Ekkor az eddig sem túl egyszerű rendszert átalakították úgy, hogy nagyobb arányban kapjanak a reformátusok is helyet a város vezetésében. Kolozsvár városa ekkor a fejedelemmel, II. Rákóczi Györggyel egyezségre jutott, amelynek értelmében a hivatalok betöltését nem csak a nációk, hanem a felekezetek szerint is váltakozóvá kellett tenni. Nyilván ez az egyezmény az unitárius kolozsváriak és a református fejedelem között jött létre. Az egyezmény megkötésekor a város nagy tanácsának háromnegyed része volt unitárius, negyede pedig református. Az egyezmény értelmében, a nagy tanácsban 25 magyar reformátusnak, 25 szász reformátusnak, 25 magyar unitáriusnak és 25 szász unitáriusnak kellett lennie. ${ }^{13}$ Ilyen körülmények közepette nagyon nehéz elképzelni is, hogyan lehetett volna a város statútumában foglaltakat betű szerint betartani, bizonyára a város hatósága a teljes tisztségviselő testületben gondolkodott, és az ottani arányokra fordította a figyelmét.

A két intézmény ispotálymestereinek névsorát vizsgálva szembetűnik, hogy például a Szentlélek-ispotálynak volt olyan vezetője is, aki hat, sőt tíz éven keresztül vezette ezt az intézményt (Gebauer Mihály, Maurer Kádár Máté). ${ }^{14}$ A Szent Erzsébet-ispotály esetében a

10 Binder Pál: Közös múltunk. Kriterion, Buk., 1982. 219; Kiss 2003. 160-192.

11 ERdő János: Teológiai tanulmányok. Unitárius Egyház, Kvár, 1996. 23.

12 SzEgedi Edit: Un oraş unitarian în perioada principilor calvini = Oraşe şi orăşeni/Városok és városlakók. Szerk. Carmen Florea-Ionuț Costea-PÁl Judit-Rüsz-Fogarasi Enikő. Argonaut, ClujNapoca, 2006. 431-437.

13 Sávai János: A székelyföldi katolikus plébániák levéltára. Agapé, Szeged, 1997.37-40 (27. jegyz).

14 A Szentlélek ispotály számadáskönyvei 1601-1650. Közzéteszi Márton Tünde-Minály Ágnes, szerk. Flóra Agnes, bev. Rüsz-Fogarasi Enikő. Transylvania Emlékeiért Tudományos Egyesület, Bp., 2006 (Kolozsvári Ispotály-számadások I). (a továbbiakban Szentlélek-ispotály számadáskönyvei) 
három-négy éves hivatalviselés volt a megszokott. ${ }^{15} \mathrm{Az}$ is megtörtént, hogy egy személy több éven át a Szentlélek-ispotályt adminisztrálta, utána pedig pár évig a Szent Erzsébet élén találjuk. Kapusi Szabó András 1658-1660 között a Szentlélek, majd 1661-1665 között a Szent Erzsébet mestere volt, Fodor Gergely 1605-1609 között a Szentlélek, ${ }^{16}$ majd 1610-1613 között a Szent Erzsébet-ispotály vezetője. ${ }^{17}$

Rendkívüli esetben, például ha valamelyik ispotálymester évközben elhunyt, a családja folytatta az adminisztrálást egy újabb választásig, vagy a másik ispotály mestere töltötte be ezt a feladatot. Így például Jacobinus Dávid egy időben mindkét ispotály mestere volt. ${ }^{18}$ Kőműves Máté halála után 1615-ben özvegye adott számot, ${ }^{19}$ az 1665-ben elhalt férj, Kapusi Szabó András helyett pedig szintén az özvegye számolt el a várossal. ${ }^{20}$ 1595-ben Nyirelt János sógora végzett számadást, ${ }^{21}$ egy másik esetben pedig az ispotálymester árvái. ${ }^{22}$

Az ispotálymesterek vagy betegség és halál okán, esetleg saját akaratukból váltak meg tisztségüktől, vagy a város vezetősége döntött úgy, hogy elmozdítja őket tisztségükből. 1662. december 22-én a centumvirek azért kellett gyorsan ispotálymestert válasszanak, mert a hivatalban lévő Prázsmári Márton tisztázatlan körülmények között megszökött anélkül, hogy munkájáról számot adott volna. ${ }^{23}$ Minden esetben a városnak kötelessége volt a megüresedett helyet minél előbb betölteni. Egy tanácsi határozatban 1614. január 18-án a százférfiak úgy fogalmaznak: „várossul ollyant válasszunk, ki nem csak szóval, hanem de facto szorgalmatosson gondgyát visselje az ispotálynak". ${ }^{24}$

A források elemzései arra engednek következtetni, hogy amennyiben az ispotálymester jól végezte teendőit, hol egyik, hol a másik ispotály élére állították, legtöbbször több éven át is vitte a tisztséget. Az is előfordult viszont, hogy ha valakit ispotálymesternek választották, de a város nem volt a gazdálkodásával megelégedve, egy év leforgása után másra bízták a feladatokat. Mindez nem gátolta meg, hogy a későbbiek során az adott mester újra megbízatást kapjon, igaz ekkor már egy társával együtt az akkora már egybeolvasztott ispotályok vezetésére. Példa erre Hosz Pál, aki 1661. január 22-től 1662. január 11-ig vezette a Szentlélek-is-

15 A Szent Erzsébet ispotály számadáskönyvei 1601-1650. Közzéteszi Flóra Ágnes-Márton Tünde Mária-Minály Ágnes, szerk. Márton Tünde Mária, bev. Rüsz-Fogarasi Enikő. Transylvania Emlékeiért Tudományos Egyesület-L’Harmattan, Bp., 2010 (Kolozsvári Ispotály-számadások II.). (a továbbiakban Szent Erzsébet-ispotály számadáskönyvei)

16 Rüsz-Fogarasi 2012. 70-73.

17 Szent Erzsébet-ispotály számadáskönyvei 124-149, 431-437.

18 A Román Nemzeti Levéltárak Kolozs megyei Osztálya, Kolozsvár (a továbbiakban RNLtKol), Kolozsvár város levéltára (a továbbiakban KvLt), Számadáskönyvek (a továbbiakban KvSzám) 8/III (1598). (Az iratok másolata: Mikrofilmgyújtemény, KvLt [a továbbiakban Mfgy], 9. tekercs.)

19 Szentlélek-ispotály számadáskönyvei 237.

20 KvSzám 34/V. (Mfgy. 75. tek.)

21 KvSzám 6/XIII (1595). (Mfgy. 7. tek.)

22 „Az tiszteletes unitária szász nátióról való I[ste]nben elnyugott bü[tes] Asztalos Peter árvái[na]k isputály mesterségiröl való regesztuma, és arról való perceptiojok és erogatiojok.” KvSzám 36/IX (1689). (Mfgy. 78. tek.)

23 „Hogy penigh Prásmári Márton SzentLéleki ispitály mester bucsuvétlen, nem mint pásztor az jubok melleól, hanem mint béres elszeökeött számadatlanul...” RNLtKol, KvLt, Tanácsülési/Közgyúlési jegyzőkönyvek (a továbbiakban KvTanJk) I/8. 67. (Mfgy. 146. tek.)

24 KvTanJk I/6. 171. (Mfgy. 145. tek.) 
potályt, majd 1671-ben és 1678-1680 között a kolozsvári egyesített ispotályok sáfára volt Bonchidai Gergellyel együtt. ${ }^{25}$

A megválasztott ispotálymestert a számvevők vezették be az ispotály vagyonába, és ők instruálták az ispotály körüli feladatok elvégzésére. Szerencsés helyzetben vagyunk, mondhatnánk, hiszen ránk maradt a Szent Erzsébet-ispotály 1586-as évi instrukciója. ${ }^{26}$ Azonban miután jobban szemügyre vesszük a szöveget, optimizmusunk alábbhagy, hiszen várakozásunk ellenére itt csupán az ispotálymester gazdálkodására vonatkozóan fogalmazzák meg a tennivalókat. A város vezetősége előírta, hogy az intézmény élén álló mester az ispotálygazdaság bevételeit kilenc fejezetbe tagolva számolja el. Az első fejezetbe a búza, vetemények, malmok, mérai jószág dézsmáját, valamint a majorságból származó javakat jegyezték. A második nagy tételbe a szőlő, azaz bor mennyiségére vonatkozó adatok kerültek. A harmadik a juhok, bárányok és az ezekkel járó járulékos bevételeket tartalmazta. A negyedik fejezetbe a sütőházakból származó kenyerek számát jegyezték fel. Az ötödik fejezet a kaszáló rétekból bejövő széna bevételét számolta el. A hatodik a pázsit és dézsmadisznók számát adja meg. A hetedik a lovak számát jegyzi le. A nyolcadik a szegények számát volt hivatott feljegyezni, az ispotályba szorgoskodó egyéb segítőszemélyekkel úgymint a lovásszal, a barompásztorral és a juhásszal egyetemben. A kilencedik fejezet újra a juhállományhoz kapcsolódóan kéri annak méreteiről a számadás idején való pontos feljegyzést. Az instrukció elrendeli, hogy az ispotálymester csak akkor térjen rá a kiadások feljegyzésére, miután minden bevételt már az előírt módon számba vett. Megjegyzik azt is, hogyha az elszámolását az ispotálymester nem a kért módon készíti el, akkor a számvevők azt nem fogadhatják el.

Ugyanebben az utasításban a kiadásokról vezetett számadást hét fejezetbe foglalva kérték az ispotály vezetőjétől. Ezek közül az első öt fejezetnek arról kellett beszámolnia, hogy milyen költségei voltak a gazdálkodó vezetőknek a szántás, vetés, aratásnál, a szőlő megmunkálásnál, a kaszálás és a szénagyüjtésnél, a juhok, pakulárok, malmok, vagyis a gazdaság fenntartásánál és múködtetésénél. A hatodik fejezetben kérték feljegyezni mindazokat a költségeket, amelyeket az ispotálylakók élelmezésével voltak kapcsolatosak, valamint amit az ispotályszolgák heti ellátására kiadtak. A hetedik, egyben utolsó számadási fejezetben a diversa apró kiadások számvetését szándékozták számon tartani. Valójában az instrukció az ispotálymestert csupán abban segítette, hogy számadását egy rendezett forma szerint vethesse papírra. Megjegyzendő, hogy az intézmény javai feletti gazdálkodásról vezetett számadáskönyvben rendszerint az ispotálymesterek készítették a számadást, azonban ritkábban az is előfordult, hogy fizetett személy vetette papírra az elszámolásukat.

A számadásokat vizsgálva arra a következtetésre juthatunk, hogy a szabályzat előírásait teljességében csak rövid ideig tartották be, ugyanis csupán az 1587-es és részlegesen az 1589es számadás készült az előírt normák szerint. ${ }^{27}$ Habár az 1589-es számadás után néhány év elszámolása hiányzik, de amikor ismét vannak számadási adataink, a megfogalmazott elveket csupán nagyvonalakban követik. ${ }^{28}$

25 KvSzám 35/V; 35/VII; 35/XII (ispotályszámadások). (Mfgy. 76. tek.)

26 RNLtKol, KvLt, Fasciculus IV, nr. 143-145.

27 KvSzám 3/XXX (1587), 4/XI (1589). (Mfgy. 3. tek.) (Szent Erzsébet-ispotály számadásai)

28 KvSzám 7/VII (1597); 9/XII (1600). (Mfgy. 9-10. tek.) (Szent Erzsébet-ispotály számadásai) 
Az ispotálymesterek beiktatása rendszerint az intézmény javainak az átadásával történt. Ha a város vezetősége problémákat észlelt az intézmény gazdálkodásában, elrendelte az ispotály javainak a számbavételét is. Ilyenkor inventáriumot készítettek a létesítmény vagyonáról, amely révén a város tudomást szerzett az ispotály anyagi állapotáról, és amely alapján a hivatalba lépő gazda is a helyzet ismeretében foghatott a munkájához. A kolozsvári Szent Erzsébet-ispotály vagyonáról 1591-ben, ${ }^{29}$ a Szentlélek-ispotályéról pedig 1601-ben készült ilyen leltár. ${ }^{30}$

A Szent Erzsébet-ispotály javait Balogdi Farkas problémás ispotálymesterségét követően leltározták fel. ${ }^{31} \mathrm{Az}$ őt követő tisztségviselőt a számba vett és papírra vetett javakba iktatták így be. Az ispotálynál több zálogos tárgy is volt letétben, és ezek közül egyiket Balogdi Farkas tovább zálogosította, de a város visszaváltotta. Valójában ez az inventárium jelzi annak a vagyonnak a nagyságát és összetettségét, amelyről az ispotálymesternek gondoskodnia kellett. Nyilván segítsége is volt ebben a munkában, hiszen a Szent Erzsébet-ispotály vagyona elég jelentősnek mondható. Ezekből az inventáriumokból nagyon sok mindenre fény derül, de sajnos nem olyan mértékben, mint amennyire reméltük. Még ha néha nagyon részletekbe menő tárgyi felsorolásokat találunk is bennük, sajnos - amint a Szent Erzsébet-ispotályról készült leltár mutatja - a meglehetősen megévődött lapok megnehezítik az adatok értelmezését. Az sem kizárt, hogy néhány oldal elkallódott, ugyanis a számadásokban olvasható javakról nem találunk semmilyen említést. ${ }^{32} \mathrm{Az}$ inventáriumból kiderül, hogy az ispotályház mellett az intézménynek volt ingatlana a város piacán, ahol bolt is múködött, sőt az udvarban állt egy „négy zsellérház”-nak mondott hely is. A városban a Szamoson és, a mérai jószág részeként, a Nádas-patakon is volt malma az ispotálynak. A mérai jószágot az ottani udvarházból igazgatták, ennek majorja is bevétellel szolgált. A város határában, a két Szamos között, a plébános majorja mellett is volt majorja az ispotálynak. Sütőháza a Szamos partján állt, és szintén a Szamoson, a Nagyhíd végében, feküdt a sörfőző háza is, amelyet Lakatos János épített újra. Az Új utca végében boltja volt az ispotálynak, mellette egy kenderes kert terült el. Három helyen volt szőlője, több mint tíz darab szántóföldje és számos rétje, továbbá erdőt is birtokolt.

A Szentlélek-ispotály vagyonát rendkívül zavaros időkben, 1601-ben veszik számba, ${ }^{33}$ a felleltározott javak intézője Reisz András ispotálymester lett. A leltár sokkal teljesebb, nincsenek betoldások vagy kihúzások benne, és fontos megjegyeznünk, hogy összefüggő lapokra volt lejegyezve. Az ispotálymester néhol apró részletekig beszámol az intézmény vagyonáról - például az ispotályház berendezésével kapcsolatosan -, máshol viszont hiányoznak a számadásokból ismert adatok, például a szőlősökről szóló információk. Alaposan leírták a Szentlélek-ispotályházat és a sütőházainak berendezéseit, sőt, a leltárban feljegyezték még a berendezési tárgyak és eszközök minőségét is.

29 A kolozsvári Szent Mihály Plébánia Levéltára (a továbbiakban KvPlébLt), Szent Erzsébet aggmenház levéltára, Inventárium, 1591, fasc. A, nr. 53.

30 KvPlébLt, Szentlélek aggmenház levéltára (a továbbiakban SztLélekLt), Inventárium, 1591, fasc. A, nr. 53.

31 Rüsz-Fogarasi Enikő: Balogdi Farkas életútja. Korunk XXII(2010). 10. sz. 28-32. (a továbbiakban Rüsz-Fogarasi 2010)

32 Például a pincéről. Szent Erzsébet-ispotály számadáskönyvei 22, 137, 179, 201, 203, 314, 335, 373, 388, 397, 398, 399, 415.

33 KvPlébLt, SztLélekLt, Inventárium, 1591, fasc. A, nr. 53. 
A megválasztott és beiktatott ispotálymesterek, akárcsak más tisztségviselők, hivatali idejük alatt adómentességet élveztek. ${ }^{34}$ Ezt nemcsak Domokos Mátyás, a Szent Erzsébet-ispotály mestere esetében lehet nyomon követni, ${ }^{35}$ hanem Fodor Gergely esetében is, ${ }^{36}$ ugyanis amikor a tisztségviselôk a város vagy az ispotály számára dolgoztak, feltehetően kijárt nekik a napszám és az élelem.

Az ispotálymester fizetségéről kevés adat maradt ránk. A Szent Erzsébet-ispotály mesterének számadásaiban elég gyakran olvashatjuk, hogy „Az mit magam asztalára költöttem”. ${ }^{37}$ Máskor a neki szánt bort jegyzik fel, ${ }^{38}$ vagy az asztalára kerülő búzáról, ${ }^{39}$ húsró1, ${ }^{40}$ szalonnáró1 ${ }^{41}$ számol el. A Szentlélek-ispotály esetében semmilyen hasonló információ nem áll rendelkezésünkre. Nyilván nem gondolhatunk arra, hogy az ispotálymester fizetség nélkül végezte ezt a sokszor terhes feladatot, csupán az a furcsa, hogy a némelykor kemény számvevői kritikával megtǔzdelt számadásokban ilyen feljegyzés nem került be, és a számvevők ezt nem is kifogásolták. Megtörténhet, hogy az ispotály bizonyos szőlősét vagy szántóját ingyen használták a mesterek, esetleg a vámkenyerekből is részt kaptak. De a kérdés az marad mégis, hogy miért nem jegyezték fel ezeket az adatokat.

$\mathrm{Az}$ ispotálymester bizonyára saját házában lakott, onnan igazgatta az intézményt, és intézte a rászorulók feletti gondoskodást. Az ispotálymesterek többnyire mesteremberek voltak, találunk közöttük ötvöst (Dési Ötvös János), ${ }^{42}$ kádárt (Maurer Kádár Máté) ${ }^{43}$ vagy mészárost (Lincz György). ${ }^{44}$ Bizonyára a város ezen tiszteletreméltó mesteremberei és egyben polgárai nem hagytak fel mesterségükkel ispotálymesteri hivataluk viselése idején sem. Ezt támasztaná alá az az adat is, amely szerint a Szent Erzsébet-ispotály mestere, Kapusi Szabó András 1661-ben az ispotálya számára nyolc hordót rendelt Kádár Mátétól, aki ekkor a város egyik adószedője volt. ${ }^{45}$

Az ispotályon kívüli szegény rászorulók feletti gondoskodás nem mindig csak az ispotálymester feladata volt. 1571.június 4-én a százférfiak tanácsa úgy határozott, hogy az egyházfiak járjanak el és oldják meg a kóborló szegények kérdését. ${ }^{46}$ Máskor azonban az ispotálymeste-

34 Minály Melinda: Telkek és tulajdonosok a kolozsvári Belmagyar utcában a XVI-XVII. században = Erdély XVII-XVIII. századi épitészetének forrásaiból. Szerk. Kovács Zsolt. Scientia, Kvár, 2004. 224, 226-227, 254.

35 Kiss András: Kolozsvár város XVI. századi adókönyveinek forrásértéke = Kiss 2003.215.

36 MiнÁLy: i. m. 226.

37 Szent Erzsébet ispotály számadáskönyvei 63, 104, 147, 427.

38 Uo. 148, 183.

39 Uo. 182.

40 Uo. 76, 133.

41 Uo. 76.

42 Rüsz-Fogarasi 2012. 88.

43 Uo. 100-104.

44 Uo. 91-92.

45 „Az kádárnak való fizetés. Köttette[m] Kadar Mathe Vramal 6 öregh hordót atta $[\mathrm{m}] \mathrm{fr}$. 2. Itte[m] kettöt egy általagot fr. - d. 20. dongat feneket vont bele fr. - d. 32. Itte $[\mathrm{m}]$ keótót két kádat d. 50. Az kádárnak való fizetés tesz fr. 3 d. 02.” KvSzám 33/XVII (1661). (Mfgy. 74. tek.) (a Szent Erzsébet-ispotály számadásai)

46 „két egyházfia mellé ókegyelmek válasszanak az tanácsbeli uraim közül kettöt kik az templom alatt heverố szegényeket lássák meg, és az kik az espotályban valók rendelje oda, az kikpenig gyermekesek volnának, 
rekre hárították a szegények és koldusok ellátásának megszervezését is, így válsághelyzetben nem csupán az intézményben található rászorultakra kellett gondot viselniük. Ilyen rendkívüli helyzetnek vagyunk tanúi 1600-ban, amikor a háborús időbeli állapotok kézbentartására a centumvirek az október 21-én tartott gyülésen a koldusok kérdésének sürgős megoldását szorgalmazták. A források tanúsága szerint a várost ellepő kéregető koldusok miatt kialakult uralhatatlan helyzet orvoslása érdekében a város vezetése úgy döntött, hogy az ispotálymesterek az egyházfiak segítségével szervezzék meg a szükségben lévők ellátását. Első lépésként megállapították, hogy a koldusok sokasága közül kik azok, akik a város szegényei és kik azok, akik a vármegyéből húzódtak be a város falai közé. Ezt követően a város vezetése felhatalmazta tisztségviselőit arra, hogy az idegen koldusokat a városból kivezethessék, remélve, hogy ezt követően meg tudja majd oldani a saját szegényeiről való gondoskodást. ${ }^{47}$ Úgy tünik, hogy az intézkedés mégsem tudta megoldani a városba özönlött menekültek, nyomorultak és rokkantak kérdését, ugyanis két hónappal később ismét a nagytanács elé került az ügy. Most azonban a tanács név szerint is megnevezte azokat, akiket az ispotálymester segítségére kijelölt. ${ }^{48}$

Ezen rendkívüli esetekben tehát az ispotálymesterek mellé a város segítséget is állított. A centumvirátus 1600. december 30-án tartott ülésén többek között a „nyomorultak és koldusoknak a városon való szertelenségéról” tárgyaltak, és a tanácstagok úgy vélték, hogy az ispotálymesterek semmiképpen sem elégségesek arra, hogy meglátogassák és gondját viseljék a rászorulóknak. Ezért a felső ispotály mestere mellé Radnaszegi Istvánt és Beck Jánost választották, az alsó ispotály mestere mellé pedig Csiszár Mihályt és Kádár Mihályt. Nem csupán segítséget rendeltek a két ispotálymester mellé, hanem meg is határozták mit vártak el tőlük. Ezek szerint az ispotálymesterek és a melléjük kirendelt személyek feladata volt, hogy minden szegény helyzetét külön-külön elbírálják, és megállapítsák ki volt az igazi rászoruló és kinek milyen segítségre volt szüksége. Abban az esetben, ha túl sok olyan szegényt találtak, akinek nem volt fedél a feje fölött, és az ispotályházban sem volt már elegendő hely, felhatalmazták őket, hogy hajlékot béreljenek, ahol meleg szállást és ételt biztosíthattak számukra. ${ }^{49}$

A szegényekkel járó költségeket többnyire az ispotály jövedelméből fizették. Amennyiben a segítség mértéke meghaladta az intézményeknek a bevételét, akkor a várostól kérhették a hiányzó összeget. Különösképpen az említett rendkívüli állapotok között a város hatóságának gyors segítségére számíthattak. A szegények kérdésével foglalkozó hatos csapat felelt az alamizsna méltányos elosztásáról, de arról is, hogy akik az alamizsnára nem voltak jogosultak,

hogj az espotálba nem férnének, azoknak ôkegyelmek rendeljenek az quartából valami segitséget vagy d. 10 vagy 20 vagy több illik, keljen az espotálybeli és azon kivül való szegényekre az öfelsége donációja. Hul penig kik az szegények közül sem espotálba nem akarnak menni, sem az segitséggel meg nem elégeznek, az, mint öfelségétól információnk vala, üzetessenek ki az városból." KvTanJk I/3. 41. (Mfgy. 143. tek.)

„A koldusok dolgáról ennek elötte is szólottanak okegyelmek, mostan is tetszett, hogy ispotály mester uraimat az egyházfiakkal egyetemben biró uram kényszerittse reá, és az idegen csalárd kuldusokat vizsgálják meg, és coacte igazitsák ki az város határáról, mert mi magunknak is elég nyomorultink vadnak az szúk idóben, csak azokat tartathassuk. Bíró uram ezt meg is kiáltassa, hogy az kuldusok az házak alól ki tisztuljanak.” KvTanJk I/5.186v. (Mfgy. 145. tek.)

48 KvTanJk I/5. 190v. (Mfgy. 145. tek.)

49 „szorgalmatoson az szegényeket meg látogassák, és megcirkálják meg, kik érdemlik meg az alamizsnát, s kik nem. Akik megérdemlik, ha azoknak az ispotályban elegedendó helyek nem lészen, tehát házat fogadjanak nekik és étellel, meleggel tartassák." Uo. 
azok ne részesülhessenek belőle. Az akkori helyzetben azonban ezek az intézkedések nem bizonyultak elégségesnek, mert a vármegyékből egyre több szegény áramlott be a városba. A város vezetősége más intézkedéseket is kénytelen volt hozni: a vármegyei szegények kikísérése mellett utasították a kapuőrző darabontoknak, hogy a vármegyéból jövố koldusokat ne engedjék be a város kapuin.

Egyébként az ispotálymesternek teljes cselekvési szabadsága volt a beiktatott javak adminisztrálásában, feladatait legjobb belátása szerint végezhette; csupán a számvevők értékelték a munkáját, néha maró iróniával, máskor kemény kritikával..$^{50}$

A gazdálkodásuk idején a számukra átadott javak fölött a döntés az ispotálymester kezében volt. Ô volt tehát az ispotály vagyonának a sáfára, és csak olyankor fordult segítségért a városi nagytanácshoz, ha jelentős, az intézmény anyagi lehetőségeit meghaladó javításokról, vagy építésekről volt szó. Abban az esetben is a tanács döntött, ha az ispotály vagyonának egy részét értékesíteni akarták. Erre talán az a legjobb példa, amikor, feltehetóen 1578-ban, a Szentlélek-ispotály mestere, a tanács határozata értelmében, a megtartott három szőlő mellett a többit eladta, az árából a megmaradt szőlőskerteket körülkerítette és az ispotályházat feljavította. $^{51}$

Úgy tủnik viszont, hogy a tanács és a bíró joghatósága alá tartozott azt eldönteni, hogy kit vegyenek be az ispotályba. ${ }^{52}$ Csak rendkívüli esetekben, például amikor a rászorulók száma jelentősen megnőtt, adták át ebben a kérdésben a döntési jogot az ispotálymesternek.

Kolozsváron a szüret megkezdését a városi tanács határozta meg, mivel így könnyebb volt a bordézsma összegyújtése. Igy minden szőlősgazda, polgár vagy intézmény egyaránt, tiszteletben kellett tartsa a szüretnek a tanács által meghatározott időpontját és sorrendjét. A szőlőszüret idôpontjának meghatározásánál az ispotályok is a városi tanács véleményét tiszteltben tartva járhattak csupán el. 1600. október 21-én a tanács úgy döntött, hogy a következő pénteken fogjanak hozzá a szürethez, de úgy, hogy a vasárnapi prédikáció alatt senki se merjen szőlőt szedni, s aki azt mégis megtenné, azt „erős büntetés” illesse. ${ }^{53} 1617$. szeptember 17-én a szőló rothadása miatt elég korai szüretet rendeltek el a város vezetôii. ${ }^{54} \mathrm{~A}$ szüret menetét, vagyis azt, hogy hol kezdődik és melyik hegyen, mikor fognak hozzá a betakarításhoz, 1617. októberében is részletesen leírták; ${ }^{55}$ egyébként a százférfiak gyúlésének egyik visszaté-

50 Lásd Werner Szőcs Péter 1624-es, a Szent Erzsébet-ispotály számadásához füzött számvevői megjegyzését: „Vottem egy eleven juhot per Fr.1 d.-. Talán elevenen nyelte el az molnármester, de hol azért a bör?’ Szent Erzsébet ispotály számadáskönyvei 265.

51 Rüsz-Fogarasi 2012. 23; Márton Tünde Mária: A kolozsvári ispotálylakók a 17. század elsó felében = Árpád-házi Szent Erzsébet. Magyar-német kultúrkapcsolatok Kelet-Közép-Európában. Szerk. GáвоR Csilla-Knecht Tamás-TAR Gabriella-Nóra. Verbum, Kvár, 2009. 214-226.

52 1624. április 27. „biró uram és becsületes tanács akaratából vöttem két szegény asszonyt be az isputaljba” Szent Erzsébet ispotály számadáskönyvei 250.

53 KvTanJk I/5. 186v. (Mfgy. 145. tek.)

54 „Látván ő kegyelmek városul az szölónek veszedelmét az rothadás miatt, tetszett annak okáért ökegyelmeknek, hogy ispotály mester uramnak szabad legyen, az régi mód szerint, az holnapi napon szedni. Közönségesen pedig az Alhegyekre az jövö hétfön költözzenek ki, és ugyan azon nap szedjenek is. Az Felhegyekre pediglen költözzenek azonképpen az régi mód szerint, harmad napon, melyet bíró uram ökegyelme publicaltasson" KvTanJk I/6. 86. (Mfgy. 145. tek.)

55 KvTanJk I/6. 241-242. (Mfgy. 145. tek.) 
rő témája az ispotályszőlő szüretelésének időpontja. A tanácsi határozatokból úgy tûnik, hogy minden alkalommal az ispotálymester kérte a szüret időpontjának a meghatározását.

A kolozsvári Szentlélek-ispotály élén az ispotályok összeolvadásáig 36 ispotálymestert tudtunk azonosítani. Munkájuk során sikerült az intézmény javait megtartaniuk és a rászoruló szegényekről is tudtak gondoskodni. Nehéz megítélni, melyik tisztségviselő végezte a legjobban a rábízott feladatokat, hiszen egyesek annak ellenére is az ispotály élén maradtak, hogy a számvevők keményen bírálták gazdálkodásukat. Ez történt Gebauer Szíjgyártó Mihály esetében is, aki 1628-1633 között vezette a Szentlélek-ispotályt. ${ }^{56}$ Legtöbbször azonban a számvevők csupán elfogadták a beszámolókat, nem füztek hozzá megjegyzéseket. Talán a számvevők és városvezetés is kedvezően ítélte meg Dési Eötvös János ténykedését, aki olyan hatékonyan gazdálkodott, hogy az intézmény bevételeiból még a városnak is juttatott, amellett pedig gondos gazdaként még a szegények hagyatékát is gyarapította. Tisztsége végeztével az ispotály évek óta veszteséges szőlősét kérte használatra a maga és felesége számára. A tanács szavazata alapján meg is kapta, és 1638-1643 között használta, ezután visszakerült az ispotály vagyonába, de már nem dolgozták meg többé. ${ }^{57}$

A Szent Erzsébet-ispotály élén is több tucat ispotálymester fordult meg az ispotályok egybeolvadásáig. Ezek közül kiemelném Fodor Gergelyt, aki 1605-1609 között a Szentlélek, majd 1610-1613 között a Szent Erzsébet-ispotályt vezette. Munkáját a városvezetés bizonyára pozitívan értékelte, amennyiben a kisebbik ispotályban való gazdálkodása után négy évre a Szent Erzsébet vagyona felett is sáfárkodhatott. ${ }^{58}$ Fodor Gergelynek nagyon hálásak lehetünk, ugyanis az ő munkája után maradt fenn az egyik legrészletesebb ispotályszámadás, amelyben nem csupán azt jegyezte fel, hogy mennyit költött a szegények kosztjára, hanem az általuk elfogyasztott élelmiszereket is leírta. ${ }^{59}$ Kanta Mihály gazdálkodása is jelentôsnek bizonyult az intézmény számára. Habár a számvevők mesterünk számadását kérdésekkel tüzdelték tele, ő mégis három és fél évet igazgatta az ispotályt. Gondoskodott az intézmény javairól, az ingó és ingatlan javak karbantartásáról, és megteremtette a gondoskodás anyagi kereteit is. ${ }^{60}$ Kanta Mihály nevével a Szent Erzsébet Kalandos-Társaság története során is találkozunk. 1623-ban neki, mint a társulat vezetőjének az idejében fordították le magyar nyelvre a társaság keretén belül a német nyelvü alapszabályzatot. ${ }^{61} 1590$-től az ötvös céhben találjuk, de számvevőként is megjelenik a forrásokban. ${ }^{62}$ Balogdi Farkas egy másik érdekes figurája a kolozsvári ispotálymestereknek, hiszen minekutána a Szent Erzsébet-ispotály mestere volt, és számos más városi feladatot ellátott, tanácsi határozattal távolította el az elégedet-

56 RüsZ-Fogarasi 2012. 82-84.

57 Uo. 23-24, 88-91.

58 Szentlélek ispotály számadáskönyvei 41-108, 225-229; Szent Erzsébet ispotály számadáskönyvei 124150, 431-438.

59 Megjegyzendő, hogy ekkor még az ispotály biztosította a meleg ételt a rászorulóknak. Szentlélek ispotály számadáskönyvei 41v , 108; Szent Erzsébet ispotály számadáskönyvei 124-150.

60 Szent Erzsébet ispotály számadáskönyvei 150-206, 445-447.

61 Kiss András: Kalandosok - Kalandos temető Kolozsvárt = Uő: Források és értelmezések. Kriterion, Buk., 1994. 83-103.

62 Jeney-Tóth Annamária: Míves emberek a kincses Kolozsvárott. Iparos társadalom a 17. századi Kolozsváron. EME-Debreceni Egyetem Történelmi Intézete, Kvár-Debrecen, 2004 (Erdélyi Tudományos Füzetek 247). 66. 
len városi közösség az intézmény éléről. Élete végén ő is a Szentlélek-ispotály gondozottjává vált. ${ }^{63}$

Az 1667-es évig mindkét kolozsvári ispotálynak külön ispotálymestere volt. Az ezt követô zavaros időket az ispotályok is megérezték. Évente két ispotálymestert is említenek forrásaink, azonban a feladatkörüket nem korlátozzák csupán egyik vagy a másik ispotályra. Ebben az időszakban a két ispotály vagyona egyesült és a rászorulókról való gondoskodás is többnyire egy helyen történt. A kutatásunk jelenlegi állása szerint még nem világos hogyan oszlott meg a két ispotálymester között a javak fölötti gondoskodás. Az viszont teljesen egyértelmú, hogy az 1668-1714 közötti időszakban gyakran (de nem mindig) fordult elö, hogy a két hivatalban lévő ispotálymester közös számadást készített $\left(1675,{ }^{64} 1676,{ }^{65} 1678,{ }^{66}\right.$ $\left.1679,{ }^{67} 1680^{68}\right)$.

Az ispotálymesterséget elvállaló kolozsvári polgárokat e tisztségük előtt vagy azt követően más közéleti szerepekben is megtaláljuk. Dési Eötvös János, ${ }^{69}$ Hermann András, ${ }^{70}$ Kádár Maurer Máté, ${ }^{71}$ Kapusi Szabó András, ${ }^{72}$ Lakatos György, ${ }^{73}$ Lutsch Péter ${ }^{74}$ és Lutsch István ${ }^{75}$ például mindannyian osztóbírákként is tevékenykedtek. Az ispotálymesterség úgy tünik, hogy nem volt könnyü feladat, és nem tekinthető a más hivatalokba való bekerülés feltételének. A források alapján nem is a fizetség, hanem többnyire az adómentesség, valamint a városi hivatalviselésből eredő előnyök miatt vállalták a kolozsvári polgárok. Eddigi ismereteink alapján nincs tudomásunk olyan ispotálymesterről, aki a későbbiekben esetleg a városbírói hivatalig is eljutott volna. A kolozsvári polgárkarrierek nem alapultak ennek a hivatalnak a viselésén, teljesen más pályát futottak be azok a polgárok, akik a legmagasabb hivatal felé irányultak. $^{76}$ De a város gondoskodott a tisztségviselőiről, így az ispotálymestereiről is amennyiben bajba jutottak.

63 Rüsz-Fogarasi 2010. 28-32.

64 KvSzám 35/I. (Mfgy. 76. tek.)

65 KvSzám 35/III. (Mfgy. 76. tek.)

66 KvSzám 35/V. (Mfgy. 76. tek.)

67 KvSzám 35/VII. (Mfgy. 76. tek.)

68 KvSzám 35/XII. (Mfgy. 76. tek.)

69 1626,1629-1631, 1636, 1638-ban. Kovács Kiss Gyöngy: A kolozsvári osztóbirói intézmény és a kibocsátott osztálylevelek. Korunk-Komp-Press, Kvár, 2012. 33.

70 1628, 1630, 1639-1640, 1654-ben. Uo. 34.

71 1654-ben. Uo.

72 1662-ben. Uo.

73 1633-1635, 1637-1640, 1642, 1647-ben. Uo.

74 1614, 1616-ban. Uo.

75 1654-ben. Uo.

76 Flóra Ágnes: Polgári karrier - polgári élet Kolozsváron a reneszánsz korában. Történelmi Szemle 2009, 4. sz. 482-501; Uő: A kora újkori kolozsvári elit portréja. Urbs. Magyar Várostörténeti Évkönyv III(2008). 139-140. 


\section{THE MASTERS OF THE ALMSHOUSES FROM THE EARLY MODERN CLUJ}

Keywords: early modern Cluj, almshouse, hospital magister, urban government, poor

In the early modern Cluj two almshouses functioned at the same time, one of them named after Saint Elizabeth, the second after the Holy Spirit. Both were under the authority of the town. Their masters - called magister xenodochii in the documents - were elected by the Assembly of the Hundred Men, the main legislative body of the town magistrate. By presenting certain aspects of their job, the study focuses on their duties, their instructions, on the way they managed the institutions, their social status and place in the society of the town. All of them were citizens of Cluj, and, besides running the hospitals, they continued their formal job as artisans, craftsmen or merchants. After completing their assignments as masters of the hospitals, the majority of them were elected in other offices of the town management. Although all of them were citizens with respectable careers, none of them had the chance to become first judge of the town.

\section{MAGIŞTRII OSPITALIERI DIN CLUJUL PREMODERN}

\section{Cuvinte-cheie: Clujul premodern, așezământ ospitalier, magistru ospitalier, guvernare orăşenească, săraci}

În Clujul premodern au funcționat în paralel două așezăminte ospitaliere: unul cu hramul Sfintei Elisabeta, celălalt cu cel al Spiritului Sfânt. Ambele instituții s-au aflat sub guvernare orășenească. Conducătorii lor - numiți de izvoare magiștri ospitalieri (magister xenodochii) - au fost desemnați de consiliul celor o sută de bărbați (centumvirat), forul cel mai important de conducere al orașului. Studiul de față prezintă atribuțiile și instrucțiunile magiștrilor, modul în care aceștia au administrat instituțiile amintite, statutul și locul lor din societatea clujeană, prezentând exemple pentru buna gospodărire a patrimoniului investit. Toți cei aleși în funcția de magistru au fost cetățeni ai orașului, care și-au continuat meșteșugul care i-a consacrat chiar și după învestirea în funcție. După terminarea stagiului mulți dintre ei au fost desemnați în alte slujbe orășenești. Cu toate că toți au fost orășeni cu cariere respectate, niciunul nu a devenit însă jude primar al orașului. 